\title{
UANG DAN MONETER DALAM SISTEM KEUANGAN ISLAM
}

\author{
Joko Hadi Purnomo \\ Sekolah Tinggi Agama Islam Al Hikmah Tuban \\ Joko.hpurnomo@gmail.com
}

\begin{abstract}
Money is a tool that can be used in conducting exchanges or transactions both goods and services in a certain area. Money is the standard of use found in goods and labor. Therefore, money is defined as a tool to measure the value of each item and service. There are two main policies in the economy called fiscal and monetary policies. Monetary policy is a policy that is carried out to control the supply and demand of money (money circulating in the community), the available money supply, the stability of the currency's value and the direction in which money will be allocated using appropriate monetary tools or instruments in order to achieve the objectives from monetary policy itself. The fiscal policy is a policy that is used to move the steps to obtain state income including tax revenue and control the direction of fiscal policy and control the amount of government spending and expenditure using fiscal tools, so that the objectives of the policy can be achieved fiscal itself in the economy. In this study, the author only focuses on discussing monetary policy and its implications for economic development in an Islamic perspective.
\end{abstract}

Keywords: money, monetary, Islamic finance system

\section{A. Latar Belakang}

Uang adalah sesuatu yang dapat diterima secara umum sebagai alat pembayaran hutang atau alat untuk melakukan pembelian barang dan jasa. Dengan kata lain, uang merupakan alat yang dapat digunakan dalam melakukan pertukaran atau transaksi baik barang maupun jasa dalam suatu wilayah tertentu. Uang adalah standar kegunaan yang terdapat pada barang dan tenaga. Oleh karena itu uang didefinisikan sebagai alat untuk mengukur nilai tiap barang dan jasa. Dengan uang barang, jasa dan pelayanan memiliki harga dan nilai.

Menurut Al Gazali, uang memiliki peran penting dalam kegiatan perekonomian. Uang merupakan salah satu nikmat Allah SWT dan penopang kehidupan dunia. Karena itu uang harus dimanfaatkan sesuai dengan ketentuan syara'. Dalam Ihya' Ulum al-Din, Al Gazali menyatakan bahwa salah satu nikmat allah adalah telah diciptakannya dinar dan dirham sehingga dengan keduanya tegakllah dunia. Dinar dan dirham adalah benda mati yang pada hakekatnya tidak 
memiliki manfaat. Akan tetapi manusia membutuhkannya agar dapat mempunyai barang-barang, makanan, pakaian dan semua kebutuhan lainnya. Lebih lanjut ia juga menyatakan bahwa dinar dan dirham merupakan perantara terhadap sesuatu yang di inginkan. Didalam dinar dan dirham tidak ada manfaat manakala tidak ada keinginan terhadap sesuatu.

Selain merupakan nikmat, uang memiliki peran sebagai senjata yang memiliki daya guna yang bernilai tinggi. Al Gazali lebih lanjut menyatakan bahwa siapa yang memiliki uang, ia bagaikan memiliki semuanya. Dengan uang manusia dapat memenuhi kebutuhan-kebutuhan dan keinginan-keinginannya terhadap barang dan jasa. Semakin banyak uang yang dimiliki, semakin banyak pula kebutuhan dan keinginan yang dapat dipenuhinya.

Semua hal yang tersebut di atas tentu memerlukan suatu kebijakan ekonomi yang tepat dari sisi pemerintah. Ada dua kebijakan yang utama dalam ekonomi yang disebut kebijakan fiskal dan moneter. Kebijakan moneter adalah suatu kebijaksanaan yang dilakukan untuk mengontrol penawaran dan permintaan uang (uang yang beredar di masyarakat), persediaan uang yang ada, stabilitas nilai mata uang dan arah kemana uang akan dialokasikan dengan menggunakan alatalat atau piranti moneter yang tepat supaya dapat dicapai tujuan dari kebijakan moneter itu sendiri. Adapun kebijakan fiskal adalah suatu kebijakan yang dipakai untuk menggerakkan langkah-langkah untuk memperoleh pendapatan Negara termasuk pendapatan dari pajak serta melakukan kontrol terhadap arah kebijakan fiskal dan kontrol terhadap besaran jumlah pengeluaran dan belanja pemerintah dengan menggunakan alat-alat fiskal, supaya dapat dicapai tujuan dari kebijakan fiskal itu sendiri di dalam ekonomi. Di dalam penelitian ini, penulis hanya focus untuk membahas kebijakan moneter dan implikasinya terhadap pembangunan ekonomi di dalam perspektif Islam.

\section{B. Uang Dalam Sistem Keuangan Islam}

1. Perspektif Uang Dalam Sistem Keuangan Islam

Upaya memenuhi kebutuhan hidup, masyarakat tidak dapat melakukan semuanya secara seorang diri. Ada kebutuhan yang dihasilkan oleh pihak lain, dan untuk mendapatkannnya seorang individu harus menukarnya dengan 
barang atau jasa yang dihasilkannya. Namun, dengan kemajuan zaman, merupakan suatu hal yang tidak praktis jika untuk memenuhi suatu kebutuhan, setiap individu harus menunggu atau mencari orang yang mempunyai barang atau jasa yang dibutuhkannya dan secara bersamaan membutuhkan barang atau jasa yang dimilikinya. Oleh karena itu, dibutuhkan suatu sarana lain yang berfungsi sebagai media pertukaran dan satuan pengukur nilai untuk melakukan sebuah transaksi. Jauh sebelum bangsa Barat menggunakan uang dalam setiap transaksinya, dunia Islam telah mengenal alat pertukaran dan pengukur nilai tersebut, bahkan Al Quran secara eksplisit menyatakan alat pengukur nilai tersebut berupa emas dan perak dalam berbagai ayat. Para fuqaha menafsirkan emas dan perak tersebut sebagai dinar dan dirham. Uang dalam bahasa Arab disebut Maal, asal katanya berarti condong, yang berarti menyondongkan mereka kearah yang menarik, dimana uang sendiri mempunyai daya penarik, yang terbuat dari logam misalnyatembaga, emas, dan perak. Menurut fiqh ekonomi Umar RA diriwayatkan, uang adalah segala sesuatu yang dikenal dan dijadikan sebagai alat pembayaran dalam muamalah manusia. Berdasarkan sejarah Islam, pada masa Rasulullah SAW. mata uang menggunakan sistem bimetallic standard (emas dan perak) demikian juga pada masa Bani Umayyah dan Bani Abassiyah. Dalam pandangan Islam mata uang yang dibuat dengan emas (dinar) dan perak (dirham) merupakan mata uang yang paling stabil dan tidak mungkin terjadi krisis moneter karena nilai intrinsik sama dengan nilai riil. Mata uang ini dipergunakan bangsa arab sebelum datangnya Islam. ${ }^{1}$

Dalam konsep ekonomi Islam uang adalah milik masyarakat (money is goods public). Barang siapa yang menimbun uang atau dibiarkan tidak produktif berarti mengurangi jumlah uang beredar yang dapat mengakibatkan tidak jalannya perekonomian. Jika seseorang sengaja menumpuk uangnya tidak dibelanjakan, sama artinya dengan menghalangi proses atau kelancaran jual beli. Implikasinya proses pertukaran dalam perekonomian terhambat. ${ }^{2}$ Disamping itu penumpukan uang/harta juga dapat mendorong manusia cenderung pada sifat-sifat tidak baik seperti tamak, rakus dan malas beramal

\footnotetext{
${ }^{1}$ Masyhuri, Teori Ekonomi Dalam Islam, (Jakarta: Raja Gratindo Persada 2008), 25.

${ }^{2}$ Ibid., 30.
} 
(zakat, infak dan sadaqah). Sifat-sifat tidak baik ini juga mempunyai imbas yang tidak baik terhadap kelangsungan perekonomian. Oleh karenanya Islam melarang penumpukan / penimbunan harta, memonopoli kekayaan, "al kanzu" sebagaimana telah disebutkan dalam QS At Taubah 34-35, yang artinya:

Hai orang-orang yang beriman, Sesungguhnya sebahagian besar dari orang-orang alim Yahudi dan rahib-rahib Nasrani benar-benar memakan harta orang dengan jalan batil dan mereka menghalanghalangi (manusia) dari jalan Allah. dan orang-orang yang menyimpan emas dan perak dan tidak menafkahkannya pada jalan Allah, Maka beritahukanlah kepada mereka, (bahwa mereka akan mendapat) siksa yang pedih, pada hari dipanaskan emas perak itu dalam neraka Jahannam, lalu dibakar dengannya dahi mereka, lambung dan punggung mereka (lalu dikatakan) kepada mereka: "Inilah harta bendamu yang kamu simpan untuk dirimu sendiri, Maka rasakanlah sekarang (akibat dari) apa yang kamu simpan itu."

Disamping itu uang yang disimpan dan tidak dimanfatkan disektor produktif (idle asset) maka jumlahnya akan semakin berkurang karena adanya kewajiban zakat bagi umat Islam. Oleh karena itu uang harus berputar (Money as flow consept). Islam sangat menganjurkan bisnis/perdagangan, investasi disektor riil. Uang yang berputar untuk produksi akan dapat menimbulkan kemakmuran dan kesehatan ekonomi masyarakat. Teori konvensional meyakini bahwa uang saat ini lebih bernilai dibanding uang di masa depan (Economic value of time vs time value of money). Teori ini berangkat dari pemahaman bahwa uang adalah sesuatu yang sangat berharga dan dapat berkembang dalam suatu waktu tertentu. Dengan memegang uang orang dihadapkan pada risiko berkurangnya nilai uang akibat inflasi. Sedangkan jika menyimpan uang dalam bentuk surat berharga maka pemilik uang akan mendapatkan bunga yang diperkirakan diatas inflasi yang terjadi. ${ }^{3}$

Teori time value of money tampak tidak akurat, karena setiap investasi selalu mempunyai kemungkinan mendapat hasil positif, negatif bahkan tidak mendapat apa-apa. Dalam teori keuangan hal ini dikenal dengan istilah risk-return relation. Disamping itu kondisi ekonomi tidak

${ }^{3}$ Edwin Mustafa, Pengenalan Eksklusif Ekonomi Islam, (Jakarta: Prenada Media Grup, 2010), 122. 
selalu menghadapi masalah inflasi. Keberadaan deflasi yang seharusnya menjadi alasan munculnya negative time value of money diabaikan oleh teory ekonomi konvensional.

Ekonomi Islam memandang waktulah yang memiliki nilai ekonomis (penting). Pentingnya waktu disebutkan Allah dalam QS.Al Ashr, yang artinya:

demi masa. Sesungguhnya manusia itu benar-benar dalam kerugian, kecuali orang-orang yang beriman dan mengerjakan amal saleh dan nasehat menasehati supaya mentaati kebenaran dan nasehat menasehati supaya menetapi kesabaran

Ekonomi Islam secara jelas telah membedakan antara money dan capital. Dalam Islam, Uang adalah adalah public good/milik masyarakat, dan oleh karenanya penimbunan uang (atau dibiarkan tidak produktif) berarti mengurangi jumlah uang beredar. Implikasinya, proses pertukaran dalam perekonomian terhambat. Disamping itu penumpukan uang/harta juga dapat mendorong manusia cenderung pada sifat-sifat tidak baik seperti tamak, rakus dan malas beramal (zakat, infak dan sadaqah). Sifat-sifat tidak baik ini juga mempunyai imbas yang tidak baik terhadap kelangsungan perekonomian. Oleh karenanya Islam melarang penumpukan / penimbunan harta, memonopoli kekayaan, al kanzu sebagaimana telah disebutkan dalam al qur'an :

Hai orang-orang yang beriman, Sesungguhnya sebahagian besar dari orangorang alim Yahudi dan rahib-rahib Nasrani benar-benar memakan harta orang dengan jalan batil dan mereka menghalang-halangi (manusia) dari jalan Allah. dan orang-orang yang menyimpan emas dan perak dan tidak menafkahkannya pada jalan Allah, Maka beritahukanlah kepada mereka, (bahwa mereka akan mendapat) siksa yang pedih, pada hari dipanaskan emas perak itu dalam neraka Jahannam, lalu dibakar dengannya dahi mereka, lambung dan punggung mereka (lalu dikatakan) kepada mereka: "Inilah harta bendamu yang kamu simpan untuk dirimu sendiri, Maka rasakanlah sekarang (akibat dari) apa yang kamu simpan itu."

Uang Dalam Pandangan al-Ghazali \& Ibnu Khaldun, Jauh sebelum Adam Smith menulis buku The Wealth of Nations pada tahun 1766 di Eropa., Abu Hamid alGhazali dalam kitabnya Ihya Ulumuddin telah membahas fungsi uang dalam perekonomian. Beliau menjelaskan, uang berfungsi sebagai media penukaran, namun uang tidak dibutuhkan untuk uang itu sendiri. Maksudnya, adalah uang 
diciptakan untuk memperlancar pertukaran dan menetapkan nilai yang wajar dari pertukaran tersebut, dan uang bukan merupakan sebuah komoditi. Menurut alGhazali, uang diibaratkan cermin yang tidak mempunyai warna, tetapi dapat merefleksikan semua warna. Maknanya adalah uang tidak mempunyai harga, tetapi merefleksikan harga semua barang. Dalam istilah ekonomi klasik disebutkan bahwa uang tidak memberikan kegunaan langsung (direct utility function), yang artinya adalah jika uang digunakan untuk membeli barang, maka barang itu yang akan memberikan kegunaan. ${ }^{4}$

Pembahasan mengenai uang juga terdapat dalam kitab Muqaddimah yang ditulis oleh Ibnu Khaldun. Beliau menjelaskan bahwa kekayaan suatu negara tidak ditentukan oleh banyaknya uang di negara tersebut, tetapi ditentukan oleh tingkat produksi negara tersebut dan neraca pembayaran yang positif. Apabila suatu negara mencetak uang sebanyak-banyaknya, tetapi bukan merupakan refleksi pesatnya pertumbuhan sektor produksi, maka uang yang melimpah tersebut tidak ada nilainya. Sektor produksi merupakan motor penggerak pembangunan suatu negara karena akan menyerap tenaga kerja, meningkatkan pendapatan pekerja, dan menimbulkan permintaan (pasar) terhadap produksi lainnya. Menurut Ibnu Khaldun, jika nilai uang tidak diubah melalui kebijaksanaan pemerintah, maka kenaikan atau penurunan harga barang semata-mata akan ditentukan oleh kekuatan penawaran (supply) dan permintaan (demand), sehingga setiap barang akan memiliki harga keseimbangan. Misalnya, jika di suatu kota makanan yang tersedia lebih banyak daripada kebutuhan, maka harga makanan akan murah, demikian pula sebaliknya. Inflasi (kenaikan) harga semua atau sebagian besar jenis barang tidak akan terjadi karena pasar akan mencari harga keseimbangan setiap jenis barang. Apabila satu barang harganya naik, namun karena tidak terjangkau oleh daya beli, maka harga akan turun kembali. ${ }^{5}$

Merujuk kepada Al-Quran, al-Ghazali berpendapat bahwa orang yang menimbun uang adalah seorang penjahat, karena menimbun uang berarti menarik uang secara sementara dari peredaran. Dalam teori moneter modern, penimbunan uang berarti memperlambat perputaran uang. Hal ini berarti memperkecil terjadinya transaksi, sehingga perekonomian menjadi lesu. Selain itu, al-Ghazali

4 A. Karim, Ekonomi Makro Islami, (Bandung: grafindo, 2008), 22.

${ }^{5}$ M. Umer Chapra. Sistem Ekonomi Islam, (Jakarta: Gema Insani press, 2000), 98 
juga menyatakan bahwa mencetak atau mengedarkan uang palsu lebih berbahaya daripada mencuri seribu dirham. Mencuri adalah suatu perbuatan dosa, sedangkan mencetak dan mengedarkan uang palsu dosanya akan terus berulang setiap kali uang palsu itu dipergunakan dan akan merugikan siapapun yang menerimanya dalam jangka waktu yang lebih panjang. ${ }^{6}$

2. Fungsi Uang dalam Ekonomi Islam

Menurut konsep Ekonomi Syariah, uang adalah uang, bukan capital, sementara dalam konsep ekonomi konvensional, konsep uang tidak begitu jelas. Misalnya dalam buku Money, Interest and Capital karya Colin Rogers, uang diartikan sebagai uang dan capital secara bergantian. Sedangkan dalam konsep ekonomi Syariah uang adalah sesuatu yang bersifat flow concept dan merupakan public goods. Capital bersifat stock concept dan merupakan private goods. Uang yang mengalir adalah public goods, sedangkan yang mengendap merupakan milik seseorang dan menjadi milik pribadi (private good). ${ }^{7}$

Islam, telah lebih dahulu mengenal konsep public goods, sedangkan dalam ekonomi konvensional konsep tersebut baru dikenal pada tahun 1980-an seiring dengan berkembangnya ilmu ekonomi lingkungan yang banyak membicarakan masalah externalities, public goods dan sebagainya. Konsep publics goods tercermin dalam sabda Rasulullah Shalallahu alaihiwasalam, yakni Tidaklah kalian berserikat dalam tiga hal, kecuali air, api, dan rumput. Berikut ini merupakan fungsi uang berdasarkan pandangan Ekonomi Islam:

a. Dalam penggunaannya sebagai alat pembayaran atau media untuk pertukaran dalam melaksanakan transaksi ekonomi, maka penggunaan uang sejalan dengan konsep ekonomi syariah. Dimana manfaat uang mencapai nilai optimum bila peredarannya berlaku optimal. Akibatnya segala kegiatan yang mengganggu pemakaian uang dalam transaksi ekonomi tidak sesuai dengan Syariah Islam. Sehingga pada saat emas dipakai sebagai uang, maka penyimpanan emas yang mengakibatkan peredaran uang terganggu (kanzul maal) dilarang oleh Syariah Islam.

\footnotetext{
${ }^{6}$ Ibid., 105

${ }^{7}$ Azwar Adiwarman. Sejarah Pemikiran Ekonomi Islam, (Jakarta: Raja Grafindo Persada, 2006), 68.
} 
b. Dalam penggunaannya sebagai sarana untuk menyimpan nilai maka penggunaan uang tidak bertentangan dengan konsep ekonomi syariah, selama uang tersebut masih bisa dipergunakan dalam kegiatan transaksi perniagaan. Oleh karena itu diperlukan adanya pihak ketiga (dalam hal ini adalah lembaga keuangan) yang menerima simpanan uang dari pihak yang ingin menyimpan nilai dan kemudian menyalurkannya kepada pihak-pihak yang ingin melakukan transaksi sehingga uang tersebut masih dapat dipergunakan dalam transaksi walaupun nilai yang disimpan oleh pemilik asal tidak berkurang.

c. Namun penggunaan uang untuk spekulasi sama sekali bertentangan dengan Syariah Islam, baik karena spekulasi tersebut tidak disukai maupun karena spekulasi umumnya berkaitan dengan menghalangi terjadinya mekanisme pasar yang wajar guna mendapatkan fluktuasi harga yang abnormal. Spekulasi juga mengakibatkan ketidak stabilan nilai dari mata uang itu sendiri karena fluktuasi harga pada hakekatnya adalah fluktuasi nilai (daya beli) dari uang itu sendiri. ${ }^{8}$

Persamaan fungsi uang dalam sistem Ekonomi Syariah dan Konvensional adalah uang sebagai alat pertukaran (medium of exchange) dan satuan nilai (unit of account). Perbedaannya adalah ekonomi konvensional menambah satu fungsi lagi sebagai penyimpan nilai (store of value) yang kemudian berkembang menjadi motif money demand for speculation, yang merubah fungsi uang sebagai salah satu komoditi perdagangan. Jauh sebelumnya, Imam al-Ghazali telah memperingatkan bahwa Memperdagangkan uang ibarat memenjarakan fungsi uang, jika banyak uang yang diperdagangkan, niscaya tinggal sedikit uang yang dapat berfungsi sebagai uang. ${ }^{9}$

Dengan demikian, dalam konsep Islam, uang tidak termasuk dalam fungsi utilitas karena manfaat yang didapatkan bukan dari uang itu secara langsung, melainkan dari fungsinya sebagai perantara untuk mengubah suatu barang menjadi barang yang lain. Dampak berubahnya fungsi uang dari sebagai alat tukar

\footnotetext{
${ }^{8}$ Ibid., 80.

${ }^{9}$ Chapra, M. Umer. The Future of Economics An Islamic Perspective, (Jakarta: terj. SEBI, 2001), 102.
} 
dan satuan nilai mejadi komoditi dapat dirasakan saat ini, yang dikenal dengan teori Bubble Gum Economic.

\section{B. Moneter Dalam Pandangan Sistem Kuangan Islam}

1. Pengertian Kebijakan Moneter

Kebijakan Moneter adalah kebijakan pemerintah untuk memperbaiki keadaan perekonomian melalui pengaturan jumlah uang beredar. Untuk mengatasi krisis ekonomi yang hingga kini masih terus berlangsung, disamping harus menata sektor riil, yang tidak kalah penting adalah meluruskan kembali sejumlah kekeliruan pandangan di seputar masalah uang. Bila dicermati, krisis ekonomi yang melanda Indonesia, juga belahan dunia lain, sesungguhnya dipicu oleh dua sebab utama, yang semuanya terkait dengan masalah uang. ${ }^{10}$

a. persoalan mata uang, dimana nilai mata uang suatu negara saat ini pasti terikat dengan mata uang negara lain (misalnya rupiah terhadap dolar AS), tidak pada dirinya sendiri sedemikian sehingga nilainya tidak pernah stabil karena bila nilai mata uang tertentu bergejolak, pasti akan mempengaruhi kestabilan mata uang tersebut.

b. kenyataan bahwa uang tidak lagi dijadikan sebagai alat tukar saja, tapi juga sebagai komoditi yang diperdagangkan (dalam bursa valuta asing) dan ditarik keuntungan (interest) alias bunga atau riba dari setiap transaksi peminjaman atau penyimpanan uang.

Persoalan kedua relatif bisa selesai andai saja semua bentuk transaksi yang di dalamnya terdapat unsur riba dinyatakan dilarang. Lembaga keuangan syariah, termasuk bank syariah, menjadi satu-satunya anak tunggal yang sah beroperasi di negeri ini menggantikan bank-bank konvensional. Dengan melarang semua transaksi ribawi, berarti telah menghilangkan factor utama penyebab labilitas moneter. Sebaliknya, tetap membiarkan bank-bank konvensional berjalan (sekalipun pada saat yang sama juga beroperasi bank-bank syariah) sama saja memelihara penyakit yang sewaktu-waktu akan memporak-porandakan kembali bangunan tubuh ekonomi Indonesia. Sementara itu, persoalan pertama diatasi dengan cara mengkaji ulang mata uang kertas yng selama beberapa puluh tahun

${ }^{10}$ Chapra M. Umer, Sistem Moneter Islam, (Jakarta: Gema Insani Press, 2000), 55. 
terakhir diterima begitu saja tanpa reserve (taken for granted), seolah tidak ada persoalan di dalamnya. Berapa banyak diantara kita yang menyangka bahwa uang kertas yang setiap hari ada di kantong kita menyimpan sebuah persoalan begitu mendasar. ${ }^{11}$

Berkenaan dengan mata uang, Islam memiliki pandangan yang khas. Abdul Qodim Zallum mengatakan bahwa sistem moneter atau keuangan adalah sekumpulan kaidah pengadaan dan pengaturan keuangan dalam suatu negara. Yang paling penting dalam setiap sistem keuangan adalah penentuan satuan dasar keuangan (al-wahdatu al-naqdiyatu alasasiyah) dimana kepada satuan itu dinisbahkan seluruh nilai-nilai berbagai mata uang lain. Apabila satuan dasar keuangan itu adalah emas, maka sistem keuangan/moneternya dinamakan sistem uang emas. Apabila satuan dasarnya perak, dinamakan sistem uang perak. Bila satuan dasarnya terdiri dari dua satuan mata uang (emas dan perak), dinamakan sistem dua logam. Dan bila nilai satuan mata uang tidak dihubungkan secara tetap dengan emas atau perak (baik terbuat dari logam lain seperti tembaga atau dibuat dari kertas), sistem keuangannya disebut sistem fiat money. Dalam sistem dua logam, harus ditentukan suatu perbadingan yang sifatnya tetap dalam berat maupun kemurnian antara satuan mata uang emas dengan perak. Sehingga bisa diukur masing-masing nilai antara satu dengan lainnya, dan bisa diketahui nilai tukarnya. Misalnya, 1 dinar emas syar'i bertanya 4,25 gram emas dan 1 dirham perak syar'iy beratnya 2,975 gram perak.

Sistem uang dua logam inilah yang diadopsi oleh Rasulullah SAW. Ketika itu kendati menggunakan sistem uang dua logam, Rasulullah SAW memang tidak mencetak dinar dan dirham emas sendiri, tapi menggunakan dinar Romawi dan dirham Persia (ini juga menunjukkan bahwa sistem uang dua logam tidak eksklusif hanya dilakukan oleh ummat Islam). Demikian seterusnya, sistem dua logam itu diterapkan oleh para khalifah hingga masa Khalifah Abdul Malik bin Marwan (79H). Baru di masa itulah dicetak dinar dan dirham khusus dengan corak Islam yang khas. Dengan cara itu, nilai nominal dan nilai intrinsik dari mata uang dinar dan dirham akan menyatu. Artinya, nilai nominal mata uang yang berlaku akan dijaga oleh nilai instrinsiknya (nilai uang itu sebagai barang, yaitu

${ }^{11}$ An-Nabhani,Taqyuddin, Membangun Sistem Ekonomi Alternatif Persektif Islam, (Surabaya : Risalah Gusti, 1996), 77. 
emas atau perak itu sendiri), bukan oleh daya tukar terhadap mata uang lain. Maka, seberapapun misalnya dollar Amerika naik nilainya, mata uang dinar akan mengikuti senilai dollar menghargai 4,25 gram emas yang terkandung dalam 1 dinar. Depresiasi (sekalipun semua faktor ekonomi dan non ekonomi yang memicunya ada) tidak akan terjadi. Sehingga gejolak ekonomi seperti sekarang ini Insya Allah juga tidak akan terjadi. Penurunan nilai dinar atau dirham memang masih mungkin terjadi. Yaitu ketika nilai emas yang menopang nilai nominal dinar itu, mengalami penurunan (biasa disebut inflasi emas). Diantaranya akibat ditemukannya emas dalam jumlah besar. Tapi keadaan ini kecil sekali kemungkinannya, oleh karena penemuan emas besar-besaran biasanya memerlukan usaha eksplorasi dan eksploitasi yang disamping memakan investasi besar, juga waktu yang lama. Tapi, andaipun hal ini terjadi, emas temuan itu akan segera disimpan menjadi cadangan devisa negara, tidak langsung dilempar ke pasaran. Secara demikian pengaruh penemuan emas terhadap penurunan nilai emas di pasaran bisa ditekan seminimal mungkin.Disinilah pentingnya ketentuan emas sebagai milik umum harus dikuasai oleh negara.

Secara syar'i pemanfaatan sistem mata uang dua logam juga selaras dengan sejumlah perkara dalam Islam yang menyangkut uang. Diantaranya tentang nisab zakat harta yang 20 dinar emas dan 200 dirham perak, larangan menimbun harta (kanzu al-mal, bukan idzkar atau saving) dimana harta yang dimaksud disitu adalah emas dan perak, sebagaimanan disebut dalam Surah At Taubah 34. Juga berkaitan dengan ketetapan besarnya diyat dalam perkara pembunuhan (sebesar 1000 dinar) atau batas minimal pencurian (1/4 dinar) untuk dapat dijatuhi hukuman potong tangan. Itu semua menunjukkan bahwa standar keuangan (monetary standard) dalam sistem keuangan Islam adalah uang emas dan perak.

Untuk menuju sistem uang dua logam, Abdul Qodim Zallum menyarankan sejumlah hal. Diantaranya, menghentikan pencetakan uang kertas dan menggantinya dengan uang dua logam dan menghilangkan hambatan dalam ekspor dan impor emas. Pemanfaatan emas sebagai mata uang tentu akan 
mendorong eksplorasi dan eksploitasi emas (mungkin secara besar-besaran) untuk mencukupi kebutuhan transaksi yang semakin meningkat. ${ }^{12}$

\section{Prinsip Dasar Kebijakan Moneter Islam}

Kebijakan moneter atau politik moneter merupakan politik negara dalam menentukan peraturan-peraturan dan tindakantindakan dalam lapangan keuangan negara. ${ }^{13}$ Secara lebih khusus kebijakan moneter mempunyai pengertian sebagai tindakan makro pemerintah melalui bank sentral dengan cara mempengarui penciptaan uang. Dengan mempengaruhi proses penciptaan uang, pemerintah bisa mempengaruhi jumlah uang beredar, yang selanjutnya pemerintah bisa mempengaruhi pengeluaran investasi, kemudian mempengaruhi permintaan agregeat dan akhirnya tingkat harga7 sehingga tercipta kondisi ekonomi sebagaimana yang diinginkan. ${ }^{14}$

Kebijakan moneter dalam Islam berbijak pada prinsipprinsip dasar ekonomi Islam sebagai berikut :

a. Kekuasaan tertinggi adalah milik Alloh dan Allohlah pemilik yang absolut.

b. Manusia merupakan Pemimpin (kholifah) di bumi, tetapi bukan pemilik yang sebenarnya.

c. Semua yang dimiliki dan didapatkan oleh manusia adalah karena seizin

Alloh, dan oleh karena itu saudara-saudaranya yang kurang beruntung memiliki hak atas sebagian kekayaan yang dimiliki saudarasaudaranya yang lebih beruntung.

d. Kekayaan tidak boleh ditumpuk terus atau ditimbun.

e. Kekayaan harus diputar.

f. Menghilangkan jurang perbedaaan antara individu dalam perekonomian, dapat menghapus konflik antar golongan.

\footnotetext{
${ }^{12}$ Muhammad, Kebijakan Fiskal dan Moneter dalam Ekonomi Islam, (Jakarta: Salemba Empat, 2002), 106

13 Taqyudin An Nabhani, Membangun Sistem Ekonomi Alternatif Perspektif Islam (Surabaya:Risalah Gusti, 1996), 52

${ }^{14}$ Budiono, Seri Sinopsis Pengantar Ilmu Ekonomi N-2.Ekonomi Makro

(Yogyakarta: BPFE, 2001), 96.
} 
g. Menetapkan kewajiban yang sifatnya wajib dan sukarela bagi semua individu, termasuk bagi anggota masyarakat yang miskin. ${ }^{15}$

\section{Konsep Ekonomi Moneter Islam}

Seperti yang telah disebutkan sebelumnya bahwa kebijakan moneter adalah proses mengatur persediaan uang sebuah Negara. Biasanya otoritas moneter dipegang oleh Bank Sentral suatu negara. Dengan kata lain, kebijakan moneter merupakan instrumen Bank Sentral yang sengaja dirancang sedemikian rupa untuk mempengaruhi variable-variabel finansial seperti suku bunga dan tingkat penawaran uang. Sasaran yang ingin dicapai adalah memelihara kestabilan nilai uang baik terhadap faktor internal maupun eksternal. Stabilitas nilai uang mencerminkan stabilitas harga yang pada akhirnya akan mempengaruhi realisasi pencapaian tujuan pembangunan suatu negara, seperti pemenuhan kebutuhan dasar, pemerataan distribusi, perluasan kesempatan kerja, pertumbuhan ekonomi riil yang optimum dan stabilitas ekonomi. ${ }^{16}$

Secara prinsip, tujuan kebijakan moneter islam tidak berbeda dengan tujuan kebijakan moneter konvensional yaitu menjaga stabilitas dari mata uang (baik secara internal maupun eksternal) sehingga pertumbuhan ekonomi yang merata yang diharapkan dapat tercapai. Stabilitas dalam nilai uang tidak terlepas dari tujuan ketulusan dan keterbukaan dalam berhubungan dengan manusia. Hal ini disebutkan AL Quran dalam QS.Al.Anam:152, yang artinya

dan janganlah kamu dekati harta anak yatim, kecuali dengan cara yang lebih bermanfaat, hingga sampai ia dewasa. dan sempurnakanlah takaran dan timbangan dengan adil. Kami tidak memikulkan beban kepada sesorang melainkan sekedar kesanggupannya. dan apabila kamu berkata, Maka hendaklah kamu Berlaku adil, Kendatipun ia adalah kerabat(mu), dan penuhilah janji Allah. yang demikian itu diperintahkan Allah kepadamu agar kamu ingat.

Kebijakan moneter sebenarnya bukan hanya mengutamakan suku bunga. Bahkan sejak zaman Rasulullah SAW dan Khulafaur Rasyidin, kebijakan moneter dilaksanakan tanpa mengunakan instrumen bunga sama sekali.Perekonomian Jazirah Arabia ketika itu adalah perekonomian dagang, bukan ekonomi yang

${ }^{15}$ Adiwarman Azwar Karim, Sejarah Pemikiran Ekonomi Islam (Jakarta: IIIT, 2001), 28

${ }^{16}$ Chapra M. Umer, Sistem Moneter Islam, (Jakarta: Gema Insani Press, 2000), 93. 
berbasis sumber daya alam; Minyak bumi belum ditemukan dan sumber daya alam lainnya terbatas. Lalu lintas perdagangan antara Romawi dan India yang melalui Arab dikenal sebagai Jalur Dagang Selatan. Sedangkan antara Romawi dan Persia disebut Jalur Dagang Utara. Sedangkan antara Syam dan Yaman disebut Jalur Dagang Utara-Selatan. Perekonomian Arab di zaman Rasulullah SAW, bukanlah ekonomi terbelakang yang hanya mengenal barter, bahkan jauh dari gambaran seperti itu. Valuta asing dari Persia dan Romawi dikenal oleh seluruh lapisan masyarakat Arab. Dinar dan Dirham juga dijadikan alat pembayaran resmi. Sistem devisa bebas diterapkan, tidak ada halangan sedikit pun untuk mengimpor dinar dan dirham.

Transaksi tidak tunai diterima luas dikalangan pedagang. Cek dan promissory notes lazim digunakan. Misalnya Umar Ibnu-Khaththab ra. Beliau menggunakan instrumen ini untuk mempercepat distribusi barang-barang yang baru diimpor dari Mesir ke Madinah. Instrumen factoring (anjak piutang) yang baru populer tahun 1980-an, telah dikenal pula pada masa itu dengan nama alhiwalah, tapi tentunya bebas dari unsur bunga.

Apabila para pedagang mengekspor barang, berarti dinar/dirham diimpor. Sebalikanya, bila mereka mengimpor barang. Berarti dinar/dirham diekspor. Jadi dapat dikatakan bahwa keseimbangan supply dan demand di pasar uang adalah derived market dari keseimbangan aggregate supply dan aggregate demand di pasar barang dan jasa. Nilai emas dan perak yang terkandung di dalam dinar dan dirham, sama dengan nilai nominalnya. Sehingga dapat dikatakan penawaran uang elastis sempurna terhadap tingkat pendapatan. Tidak ada larangan impor dirham dan dinar berarti penawaran uang elastis.Adapun instrumen moneter syariah adalah hukum syariah. Hampir semua instrumen moneter pelaksanaan kebijakan moneter konvensional maupun surat berharga yang menjadi underlyingnya mengandung unsur bunga. Oleh karena itu instrumen-instrumen konvensional yang mengandung unsur bunga (bank rates, discount rate, open market operation dengan sekuritas bunga yang ditetapkan didepan) tidak dapat digunakan pada pelaksanaan kebijakan moneter berbasis Islam. Tetapi sejumlah instrument kebijakan moneter konvensional menurut sejumlah pakar ekonomi Islam masih 
dapat digunakan untuk mengontrol uang dan kredit, seperti Reserve Requirement, overall and selecting credit ceiling, moral suasion and change in monetary base.

Dalam ekonomi Islam, tidak ada sistem bunga sehingga bank sentral tidak dapat menerapkan kebijakan discount rate tersebut. Bank Sentral Islam memerlukan instrumen yang bebas bunga untuk mengontrol kebijakan ekonomi moneter dalam ekonomi Islam. Dalam hal ini, terdapat beberapa instrumen bebas bunga yang dapat digunakan oleh bank sentral untuk meningkatkan atau menurunkan uang beredar. Penghapusan sistem bunga, tidak menghambat untuk mengontrol jumlah uang beredar dalam ekonomi. ${ }^{17}$

\section{Orientasi Sejarah Kebijakan Moneter Rasulullah}

Perekonomian jazirah arabia ketika jaman rasul merupakan ekonomi dagang bukan ekonomi yang berbasis sumber daya alam. Minyak bumi belum ditemukan dan sumber daya lainnya masih terbatas. Lalu lintas perdagangan antara romawi dan India yang melalui Arab dikenal sebagai jalur dagang selatan. Sedangkan antara Romawi dan Persia disebut sebagai jalur dagang utara. Antara Syam dan Yaman disebut jalur dagang utara selatan.

Perekonomian Arab pada jaman rosululloh, bukan ekonomi terbelakang yang hanya mengenal barter, bahkan jauh dari gambaran seperti itu. Pada masa itu telah terjadi

a. Valuta asing dari persia dan romawi yang dikenal oleh seluruh lapisan masyarakat Arab, bahkan menjadi alat bayar resminya adalah dinar dan dirham.

b. Sistem devisa bebas ditetapkan, tidak ada halangan sedikitpun untuk mengimpor dinar dan dirham.

c. Transaksi tidak tunai diterima secara luas dikalangan pedagang.

d. Cek dan Promissory note lazim digunakan, misalnya Umar Bin Khottob menggunakan instrumen ini ketika melakukan impor barang-barang yang baru dari Mesir ke Madinah.

${ }^{17}$ Sholahuddin, Asas-asas Ekonomi Islam, (Jakarta: PT.Raja Grafindo Persada, 2007), 140. 
e. Instrumen factory (anjak utang) yang baru populer pada tahun 1980-an telah dikenal dengan nama hiwalah, tetapi tentunya bebas dari unsur riba. ${ }^{18}$

Pada masa itu, bila penerimaan akan uang meningkat, maka dinar dan dirham diimpor. Sebaliknya bila permintaan uang turun, maka komoditaslah yang diimpor. Nilai emas maupunperak yang terkandung dalam koin dinar maupun dirham sama dengan nilai nominalnya, sehingga dapatlah dikatakan bahwa penawaran uang cukup elastis. Kelebihan penawaran uang dapat diubah menjadi barang perhiasan. Kondisi ini dapat menyebabkan permintaan dan penawaran uang cukup stabil. ${ }^{19}$

Permintaan akan uang hanya untuk keperluan transaksi dan berjaga-jaga. Permintaan uang untuk spekulasi tidak ada, dan penimbunan mata uang juga dilarang. Transaksi TalaqqiRukhban dengan mencegat penjual dari kampung diluar kotauntuk mendapat keuntungan dari ketidaktahuan harga juga tak diizinkan, karena akan menimbulkan distorsi harga yang kemudian menyebabkan spekulasi. $^{20}$

\section{Strategi Kebijakan Ekonomi Islam}

Dalam sebuah perekonomian Islam, permintaan terhadap uang akan lahir terutama dari motif transaksi dan tindakan berjaga-jaga yang ditentukan pada umumnya oleh tingkatan pendapatan uang dan distribusinya. Permintaan terhadap uang karena motif spekulatif pada dasarnya didorong oleh fluktuasi suku bunga pada perekonomian kapitalis. Suatu penurunan dalam suku bunga dibarengi dengan harapan tentang kenaikannya akan mendorong individu dan perusahaan untuk meningkatkan jumlah uang yang dipegang. Karena suku bunga seringkali berfluktuasi pada perekonomian kapitalis, terjadilah perubahan terus-menerus dalam jumlah uang yang dipegang oleh publik. Penghapusan bunga dan kewajiban membayar zakat dengan laju 2,5 persen per tahun tidak saja akan meminimalkan permintaan spekulatif terhadap uang dan mengurangi efek suku bunga terkunci, tetapi juga akan memberikan stabilitas yang lebih besar bagi

\footnotetext{
${ }^{18}$ Adiwarman Azwar Karim, Ekonomi Islam, Suatu Kajian Kontemporer, (Jakarta: Gema Insani Press, 2001), 28,

${ }^{19}$ Karim, Sejarah Pemikiran Ekonomi Islam, 130.
} 
permintaan total terhadap uang. Hal ini lebih jauh akan diperkuat oleh sejumlah faktor antara lain sebagai berikut :

a. Aset pembawa bunga tidak akan tersedia dalam sebuah perekonomian Islam, sehingga orang yang hanya memegang dana likuid menghadapi pilihan apakah tidak mau terlibat dengan resiko dan tetap memegang uangnya dalam bentuk cash tanpa memperolah keuntungan, atau turut berbagi resiko dan menginvestasikan uangnya pada aset bagi hasil sehingga mendapatkan keuntungan.

b. Peluang investasi jangka pendek dan panjang dengan berbagai tingkatan resiko akan tersedia bagi para investor tanpa memandang apakah mereka adalah pengambil resiko tinggi atau rendah, sejauh mana resiko yang dapat diperkirakan akan diganti dengan laju keuntungan yang diharapkan.

c. Barangkali dapat diasumsikan bahwa -kecuali dalam keadaan resesi-tak akan ada pemegang dana yang cukup irasional untuk menyimpan sisa uangnya setelah dikurangi oleh keperluan-keperluan transaksi dan berjaga-jaga selama ia dapat menggunakan sisanya yang menganggur untuk melakukan investasi pada aset bagi hasil untuk menggantikan paling tidak sebagian efek erosif zakat dan inflasi, sejauh dimungkinkan dalam sebuah perekonomian Islam.

d. Laju keuntungan -bebeda dari laju suku bunga- tidak akan ditentukan di depan. Satu-satunya yang akan ditentukan di depan adalah rasio bagi hasil, ini tidak akan mengalami fluktuasi, seperti halnya suku bunga karena ia akan didasarkan pada konvensi ekonomi dan sosial, dan setiap ada perubahan didalamnya akan terjadi lewat tekanan kekuatan-kekuatan pasar sesudah terjadi negosiasi yang cukup lama. Jika prospek ekonomi cerah, keuntungan secara otomatis akan meningkat. Karena itu, tidak ada apa pun yang didapat dengan menunggu. ${ }^{21}$

\section{Manajemen Moneter Islam}

Dasar pemikiran ini adalah terciptanya stabilitas permintaan uang dan mengarahkan pemerintahan uang tersebut kepada tujuan yang penting dan produktif sehingga, setiap instrument yang akan mengarahkan kepada instabilitas

${ }^{21}$ Muhammad, Kebijakan Fiskal dan Moneter Dalam Ekonomi Islam, (Jakarta: Salemba Empat, 2002), 88 . 
dan pengalokasian sumber dana yang tidak produktif akan di tinggalkan. Sesuai dengan ajaran Islam, manajemen moneter yang efisien dan adil tidak berdasarkan pada mekanisme bunga, melainkan dengan menggunakan instrumen utama yaitu:

a. Value Judgement yang dapat menciptakan suasana yang memungkinkan alokasi dan distribusi sumber yang sesuai dengan ajaran Islam. Pada dasarnya sumber daya merupakan amanah dari Allah yang pemanfaatannya dilakukan secara efisien dan efektif. Berdasarkan nilai-nilai Islam, permintaan uang harus dimanfaatkan untuk memenuhi kebutuhan dasar dan investasi yang produktif bukan untuk konsumsi yang berlebihan, pengeluaran-pengeluaran non produktif dan spekulatif.

b. Kelembagaan yang berkaitan dengan kegiatan social ekonomi dan politik yang salah satunya dapat menciptakan mekanisme harga yang dapat meningkatkan efisiensi dalam pemanfaatan sumber.

c. Mekanisme lembaga perantara keuangan yang beroperasi berdasarkan system bagi hasil (profit dan loss sharing). Dalam system ini permintaan uang akan dialokasikan dengan syarat hanya untuk proyek-proyek yang bermanfaat dan hanya kepada debitur yang mampu mengelola proyek secara efisien. Dengan persyaratan tersebut diharapkan dapat meminimalisasikan permintaan uang untuk pemanfaatan tidak berguna, non produktif dan spekulatif. Selain itu dapat menciptakan masyarakat yang memiliki jiwa kewirausahaan sekalipun dari golongan miskin. Karena wirausahawan dapat menghasilkan output, perluasan kesempatan kerja dan pemenuhan kebutuhan dasar.

Untuk menciptakan keseimbangan antara money demand dan money supply banyak pendekatan praktis yang dapat digunakan untuk memperkirakan permintaan uang yang konsisten dengan realisasi pencapaian tujuan sosio ekonomi dengan kerangka stabilitas harga dan kemudian memantapkan rentangan target pertumbuhan penawaran uang yang akan membantu tercapainya kecukupan permintaan ini secara memungkinkan. Pentargetan moneter sebanding dengan perputaran uang yang dapat diprediksikan secara nalar pada periode yang tepat. ${ }^{22}$

${ }^{22}$ Ibid., 90. 
4. Kebijakan Moneter Pada Masa Rasulullah.

Seperti yang telah kita ketahui bahwa mata uang yang digunakan bangsa arab, baik sebelum atau sesudahnya, adalah dinar dan dirham. Kedua mata uang tersebut memiliki nilai uang yang tetap dan karenanya tidak ada masalah dalam perputaran uang. Walaupun demikian, dalam perkembangan berikutnya, dirham lebih umum digunakan daripada dinar. Hal ini sangat berkaitan erat dengan penaklukan tentara Islam terhadap hampir seluruh wilayah kekaisaran Persia. Sementara itu, tidak semua wilayah kekaisaran Romawi berhasil dikuasai oleh tentara Islam.

Pada masa pemerintahan Nabi Muhammad SAW ini, kedua mata uang tersebut diimpor, dinar dari Romawi dan dirham dari Persia. Besarnya volume dinar dan dirham yang diimpor dan juga barang-barang komoditas bergantung kepada volume komoditas yang diekspor ke dua negara tersebut dan wilayah-wilayah lain yang berada dibawah pengaruhnya. Lazimnya, uang akan diimpor jika permintaan uang (money demand) pada pasar internal mengalami kenaikan. Dan sebaliknya, komoditas akan diimpor apabila permintaan uang mengalami penurunan. ${ }^{23}$

Karena tidak adanya pemberlakuan tarif dan bea masuk pada barang impor, uang diimpor dalam jumlah yang cukup untuk memenuhi permintaan internal. Pada sisi lain, nilai emas dan perak pada kepingan dinar dan dirham sama dengan nilai nominal (face value) uangnya, sehingga keduanya dapat dibuat perhiasan atau ornamen. Dengan demikian, dapat disimpulkan bahwa pada awal periode Islam, penawaran uang (money suply) terhadap pendapatan, sangat elastis. Frekuensi transaksi perdagangan dan jasa, menciptakan permintaan uang. Karena itu motif utama permintaan terhadap uang pada masa ini adalah permintaan transaksi (transaction demand). Sementara itu adanya peperangan antara kaum Quraisyi dan kaum muslimin (sedikitnya terjadi 26 ghozwah dan 32 sariyah yang berarti rata-rata 5 kali perang dalam setiap tahunnya), telah

${ }^{23}$ M. Syafi'i Antonio, Bank Syariah Dari Teori Ke Praktik, (Jakarta: Gema Insani Press, 2001), 43. 
menimbulkan permintaan uang untuk berjaga-jaga (precautionary demand) terhadap kebutuhan yang tidak terduga. Akibatnya, permintaan terhadap uang selama periode ini secara umum bersifat permintaan transaksi dan pencegahan. Larangan penimbunan, baik uang maupun komoditas, dan talqqi rukhban tidak memberikan kesempatan kepada penggunaan uang dengan selain kedua motif tersebut.

Ketika penduduk arab banyak yang memeluk agama islam, jumlah populasi kaum muslimin berkembang dengan pesat. Disamping itu, harta rampasan perang (ghonimah) dibagikan kepada seluruh kaum muslimin, sehingga standar hidup dan pendapatan mereka meningkat. Berdasarkan semua ini, Nabi Muhammad SAW, melalui kebijakan khususnya, meningkatkan kemampuan produksi dan ketenagakerjaan kaum muslimin secara terus menerus. Keseluruhan faktor ini meningkatkan permintaan transaksi terhadap uang dalam perekonomian periode awal Islam.

Disamping itu, penawaran uang tetap elastis karena tidak ada hambatan terhadap impor uang ketika permintaan terhadapnya mengalami kenaikan. Disisi lain, ketika penawaran akan naik, penawaran berlebih (exces supply) akan diubah secara mudah menjadi ornament emas atau perak. Akibatnya, tidak ada penawaran atau permintaan berlebih terhadap mata uang emas dan perak sehinga pasar akan selalu tetap pada keseimbangan (equilibrium). Oleh karena itu, nilai uang tetap stabil.

\section{Kesimpulan}

Bunga sesungguhnya merupakan permasalahan yang mengakibatkan ketidakstabilan perekonomian, karena jelas dalam Al-qur'an bahwa riba itu sangat dilarang atau haram. Hikmah dari pelarangan riba ini adalah agar terjadi hubungan patnership antara pemilik modal dan usaha secara adil. Dalam perekonomian Islam, sektor perbankan tidak mengenal Instrumen suku bunga. Sistem keuangan Islam menerapkan sistem pembagian keuntungan dan kerugian (profit and loss sharing), bukan dengan tingkat bunga yang telah menetapkan tingkat keuntugan di muka. Besar kecilnya pembagian keuntungan yang diperoleh nasabah 
perbankan Islam ditentukan besar kecilnya keuntungan yang diperoleh Bank dalam kegiatan investasi dan pembiayaan yang dilakukan pada sektor riil. Jadi, dalam keuangan Islam, hasil dari investasi dan pembiayaan yang dilakukan bank dalam sektor riil yang menentukan besar kecilnya pembagian keuntungan di sektor moneter. Artinya sektor moneter memiliki ketergantungan terhadap sektor riil.

Satu hal perlu menjadi perhatian, bahwa menejemen moneter Islam, yang selama ini dipraktekkan pada berbagai Negara, membawa efek positif pada sekala periode jangka panjang, akan tetapi, sulit untuk menjadi obat mujarab bagi jangka pendek. Untuk memecahkan persoalan jangka pendek, instrument yang paling memungkinkan adalah Moral suasion (bujukan Moral) dan statutory resever requiremert, berupa peningkatan cadangan wajib.

\section{Daftar Pustaka}

Antonio M. Syafi'i, Bank Syariah Dari Teori Ke Praktik, Jakarta: Gema Insani Press, Tazkia Cendikia, 2001.

Chapra M. Umer, Masa Depan Ilmu Ekonomi Sebuah Tinjauan Islam, Jakarta: Gema Insani Press, 2000.

Chapra M. Umer, Sistem Moneter Islam, Jakarta: Gema Insani Press, Tazkia Cendikia, 2000.

Huda, Nurul, dkk, Ekonomi Makro Islami Pendekatan Teoritis, Kencana, Jakarta, 2008.

Karim, Adiwarman azwar. Ekonomi Makro Islami, Raja Gratindo Persada, Jakarta. 2008.

Karim, adiwarman azwar. Sejarah Pemikiran Ekonomi Islam, Raja Grafindo Persada, Jakarta, 2006.

Muhammad, Kebijakan Fiskal dan Moneter Dalam Ekonomi Islam, Jakarta: Salemba Empat, 2002.

Muhammad, Kebijakan Fiskal dan Moneter dalam Ekonomi Islam, Salemba Empat, Jakarta, 2002.

Nasution, Mustafa Edwin, Pengenalan Eksklusif Ekonomi Islam, Prenada Media Grup, Jakarta 2010. 